\title{
THE EFFECT OF COGNITIVE BEHAVIOR THERAPY AND ELIP METHODS ON BOUNDING BREASTFEEDING AMONG MADURA TRIBE BLUES POST PARTUM
}

\author{
Elly Dwi Masita, Adenia Dwi Ristanti
}

Faculty of Nursing and Midwifery, Universitas Nahdaltul Ulama Surabaya

\begin{abstract}
Background: Until now, the prevalence of post partum blues has increased every year in all countries. In developed countries such as America, the prevalence of post partum blues from $25 \%$ in 2010 to $85 \%$ in 2015 . In Asia $20 \%-60 \%$ of postpartum women experience post partum blues out of 1000 live births, while in Indonesia it reaches $15 \%$. which was carried out in February 2020 in the northern Surabaya region with the target of postpartum mothers 48 hours to the seventh, 27 out of 33 postpartum mothers showed symptoms of post partum blues with various levels. This figure means that $81 \%$ of mothers giving birth experience post partum blues and this results in the bounding of mother and child, decreases in lactation hormones and even continues to become psichosys. The purpose of this study was to determine the quality of bounding and breastfeeding behavior in postpartum mothers with post partum blues in urban Madura, Surabaya.

Subejcts and Method: This was an experimental study with non-equivalent control group design conducted in urban Madura, Surabaya. A total of 80 mothers included in this study were divided into 50 mothers as the CBT and 30 mothers as the ELIP groups. The dependent variable was the incidence of post partum blues. The dependent variables were quality of bounding and breastfeeding behavior. The data were collected using qusttionaire then analyzed using t-test.

Results: There was a difference in bounding quality (Mean $=6.68 ; \mathrm{p}=0.003$ ) with breastfeeding behavior (Mean $=6.32 ; \mathrm{p}=0.004$ ) on the incidence of post partum blues.

Conclusion: There is a difference in bounding quality with breastfeeding behavior on the incidence of post partum blues.
\end{abstract}

Keywords: bounding, behavior, breastfeeding, CBT, ELIP

Correspondence:

Elly Dwi Masita. Faculty of Nursing and Midwifery, Universitas Nahdaltul Ulama Surabaya.

Email: ellydm@unusa.ac.id 